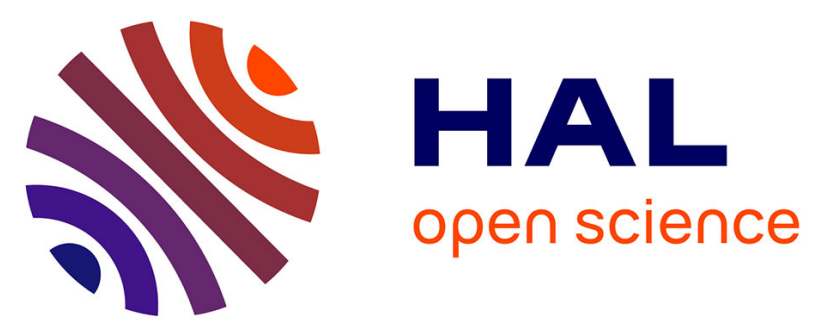

\title{
Bioinspired Oxidation of Methane in the Confined Spaces of Molecular Cages
}

Sk Asif Ikbal, Cédric Colomban, Dawei Zhang, Magalie Delecluse, Thierry

Brotin, Véronique Dufaud, Jean-Pierre Dutasta, Alexander Sorokin, Alexandre Martinez

\section{To cite this version:}

Sk Asif Ikbal, Cédric Colomban, Dawei Zhang, Magalie Delecluse, Thierry Brotin, et al.. Bioinspired Oxidation of Methane in the Confined Spaces of Molecular Cages. Inorganic Chemistry, 2019, 58 (11), pp.7220-7228. 10.1021/acs.inorgchem.9b00199 . hal-02129474

\section{HAL Id: hal-02129474 https://hal.science/hal-02129474}

Submitted on 23 Mar 2020

HAL is a multi-disciplinary open access archive for the deposit and dissemination of scientific research documents, whether they are published or not. The documents may come from teaching and research institutions in France or abroad, or from public or private research centers.
L'archive ouverte pluridisciplinaire HAL, est destinée au dépôt et à la diffusion de documents scientifiques de niveau recherche, publiés ou non, émanant des établissements d'enseignement et de recherche français ou étrangers, des laboratoires publics ou privés. 


\title{
Bioinspired Oxidation of Methane in the Confined Spaces of Molecular Cages
}

\author{
Ikbal, S. A. \\ Colomban, $C$. \\ Zhang, D. W. \\ Delecluse, $\mathrm{M}$. \\ Brotin, $\mathrm{T}$. \\ Dufaud, V. \\ Dutasta, J. P. \\ Sorokin, A. B. \\ Martinez, A.
}

\begin{abstract}
Non-heme iron, vanadium, and copper complexes bearing hemicryptophane cavities were evaluated in the oxidation of methane in water by hydrogen peroxide. According to ${ }^{1} \mathrm{H}$ nuclear magnetic resonance studies, a hydrophobic hemicryptophane cage accommodates a methane molecule in the proximity of the oxidizing site, leading to an improvement in the efficiency and selectivity for $\mathrm{CH}_{3} \mathrm{OH}$ and $\mathrm{CH}_{3} \mathrm{OOH}$ compared to those of the analogous complexes devoid of a hemicryptophane cage. While copper complexes showed low catalytic efficiency, their vanadium and iron counterparts exhibited higher turnover numbers, $\leq 13.2$ and $\leq 9.2$, respectively, providing target primary oxidation products $\left(\mathrm{CH}_{3} \mathrm{OH}\right.$ and $\left.\mathrm{CH}_{3} \mathrm{OOH}\right)$ as well as over-oxidation products $(\mathrm{HCHO}$ and $\mathrm{HCOOH})$. In the case of caged vanadium complexes, the confinement effect was found to improve either the selectivity for $\mathrm{CH}_{3} \mathrm{OH}$ and $\mathrm{CH}_{3} \mathrm{OOH}(\leq 15 \%)$ or the catalytic efficiency. The confined space of the hydrophobic pocket of iron-based supramolecular complexes plays a significant role in the improvement of both the selectivity ( $\leq 27 \%$ for $\mathrm{CH}_{3} \mathrm{OH}$ and $\mathrm{CH}_{3} \mathrm{OOH}$ ) and the turnover number of methane oxidation. These results indicate that the supramolecular approach is a promising strategy for the development of efficient and selective bioinspired catalysts for the mild oxidation of methane to methanol.

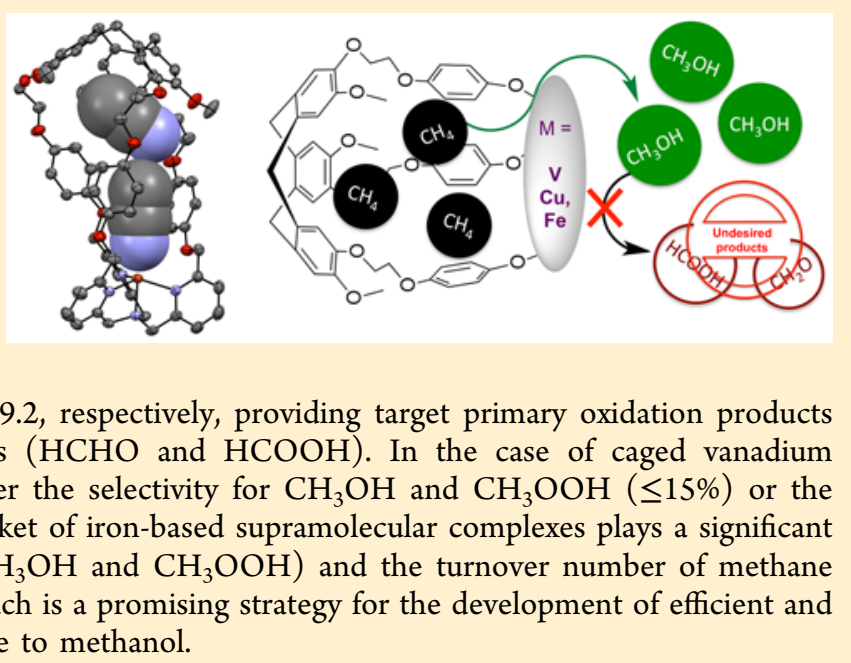

\section{INTRODUCTION}

The direct conversion of methane to methanol under mild conditions is one of the major challenges posed to the scientific community because of its crucial industrial and ecological benefits. The selective transformation of $\mathrm{CH}_{4}$ is considered as a particularly difficult task due to the extreme inertness of the methane $\mathrm{C}-\mathrm{H}$ bond (bond dissociation energy of $104.9 \mathrm{kcal}$ $\mathrm{mol}^{-1}$, high $\mathrm{p} K_{\mathrm{a}}$, low polarizability, high ionization potential, and negligible electron affinity). ${ }^{1}$ The current industrial approach to conversion of $\mathrm{CH}_{4}$ to useful products is based on syngas technology demanding large investments and very high temperatures $\left(>600{ }^{\circ} \mathrm{C}\right)$. Direct oxidation processes also require high temperatures, but the conversion and selectivity of these processes are still low. ${ }^{2}$ In contrast, in nature, the aerobic oxidation of $\mathrm{CH}_{4}$ to $\mathrm{CH}_{3} \mathrm{OH}$ under ambient conditions is efficiently mediated by the soluble (sMMO) and particulate (pMMO) methane monooxygenases found in aerobic methanotrophic bacteria. ${ }^{3-6}$ The active sites of these two enzymes are described as non-heme diiron (sMMO) and copper (pMMO) high-valence metal-oxo species, respectively, acting as particularly powerful oxidants. ${ }^{7}$ In these systems, the active metal center is confined in the hydrophobic cavity provided by the enzymatic architecture. This isolated and constrained hydrophobic environment allows for highly efficient recognition of methane and prevents back-diffusion of $\mathrm{CH}_{3} \mathrm{OH}$ to the active site, thus preventing its further oxidation. ${ }^{8}$ This structural organization results in the remarkable efficiency and selectivity of the oxidation of $\mathrm{CH}_{4}$ to $\mathrm{CH}_{3} \mathrm{OH}$. There has been an extensive effort to obtain synthetic structural models for the $\mathrm{MMO} ;{ }^{9}$ however, functional models capable of oxidizing methane are still rare. ${ }^{10}$ Among notable examples of bioinspired catalysts are non-heme copper $^{11}$ and heme diiron complexes, ${ }^{12,13}$ recently described for the mild oxidation of $\mathrm{CH}_{4}$. For instance, $\mu$-nitrido diiron phthalocyanine ${ }^{12}$ and porphyrin ${ }^{13}$ complexes were found to efficiently catalyze the oxidation of $\mathrm{CH}_{4}$ by $\mathrm{H}_{2} \mathrm{O}_{2}$ in water at 25-60 ${ }^{\circ} \mathrm{C}$. However, because the primary methane oxidation products $\left(\mathrm{CH}_{3} \mathrm{OH}\right.$ and $\left.\mathrm{CH}_{2} \mathrm{O}\right)$ contain more reactive $\mathrm{C}-\mathrm{H}$ bonds than $\mathrm{CH}_{4}$, their further oxidation occurred, providing 


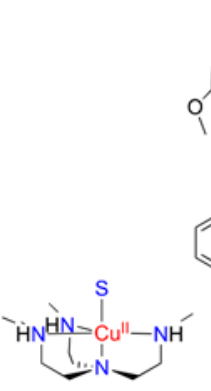

Cull(TREN) $\mathrm{S}=$ Solvent

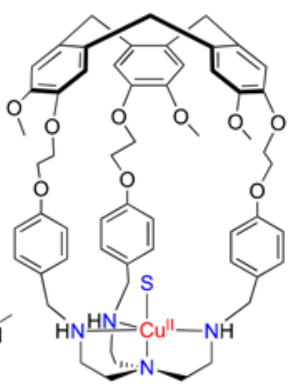

Cu"(Hm-TREN) $\mathrm{S}=$ Solvent

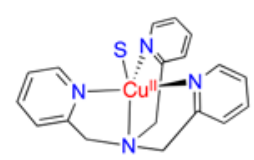

Cull(TPA) $\mathrm{S}=$ Solvent

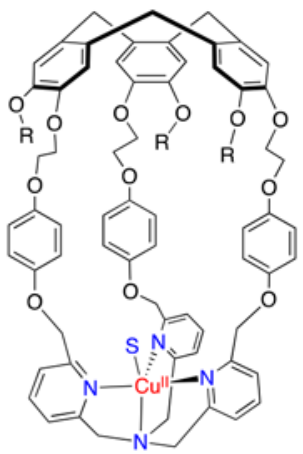

Cu'(Hm-TPA $): \mathrm{R}=\mathrm{CH}_{3}$ Cu'(Hm-TPA-COO') : $\mathrm{R}=\mathrm{CH}_{2} \mathrm{COO}$. $\mathrm{S}=$ Solvent

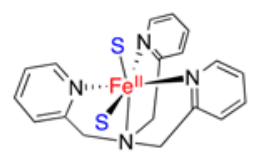

Fe"l(TPA) $\mathrm{S}=$ Solvent

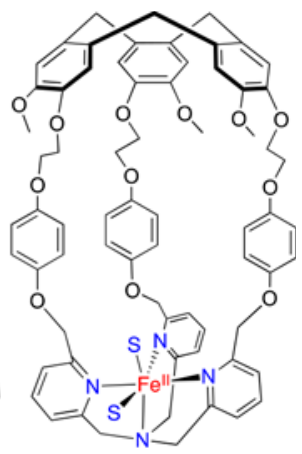

Fe"l(Hm-TPA) $\mathrm{S}=$ Solvent

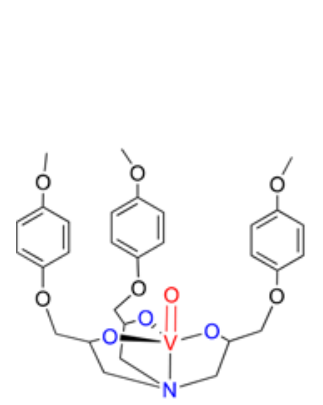

V(TKA)

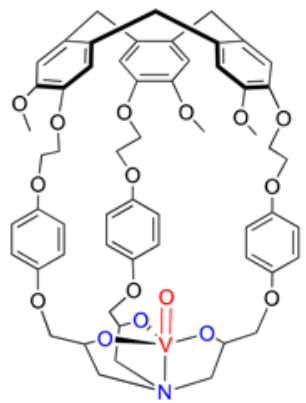

V(Hm-TKA)

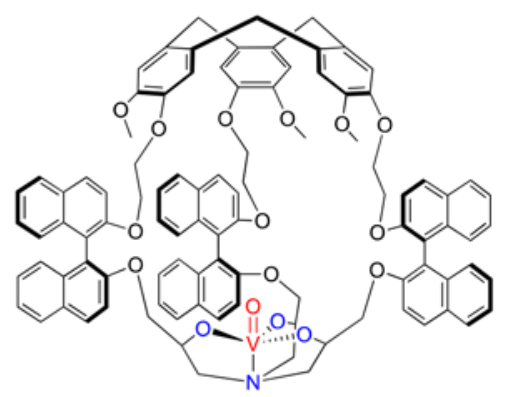

V(Hm-BINOL-TKA)

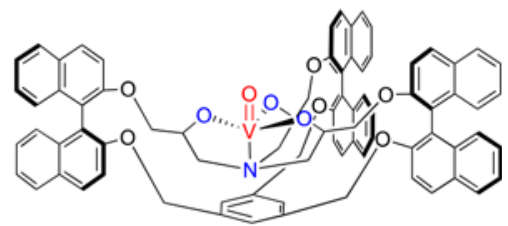

V(Bz-BINOL-TKA) formic acid with a selectivity of $88-97 \%$. Despite the need to prevent over-oxidation of $\mathrm{CH}_{3} \mathrm{OH}$, the implementation of this strategy in biomimetic methane partial oxidation systems is still overlooked. ${ }^{14}$ Consequently, to increase the selectivity of methane oxidation for methanol, the structural organization of the active site should be improved. Several approaches to circumventing the higher reactivity of the alkane oxidation products and limiting the over-oxidation reactions have been proposed. The controlled selective oxidations of aliphatic $\mathrm{C}-\mathrm{H}$ bonds have recently been achieved by supramolecular catalysts either by introducing a recognition group bound to the catalyst (interactions with the substrate such as hydrogen bonding, ${ }^{15}$ ligand to metal coordination, ${ }^{16}$ or hydrophobic effects $)^{17}$ or by building a hydrophobic cavity above the catalytic center. ${ }^{18}$ It is in this last category that $\mathrm{Cu}(\mathrm{II}){ }^{19}{ }^{19}$ and $\mathrm{V}(\mathrm{V})$-based hemicryptophanes $^{20}$ have been recently described as being highly efficient and selective oxidation catalysts compared to the parent analogues that are devoid of a cavity. Although improvements in reactivity and selectivity of various reactions have been achieved using functionalized molecular nanoreactors, ${ }^{21}$ to the best of our knowledge, such a strategy has never been extended to the bioinspired oxidation of methane. The presence of a hydrophobic cavity in the proximity of the catalytic site might result in the preferential binding of $\mathrm{CH}_{4}$ with respect to the more polar $\mathrm{CH}_{3} \mathrm{OH}$ product and favor $\mathrm{CH}_{4}$ oxidation over over-oxidation reactions. Thus, the more selective oxidation to $\mathrm{CH}_{3} \mathrm{OH}$ can be achieved. Therefore, the development of novel artificial models that can simultaneously bind and oxidize methane is highly desirable for exploring the benefits of the supramolecular approach. We present herein a study of the encapsulation and oxidation of methane mediated by vanadium, copper, and iron supramolecular complexes under mild conditions. The interaction between $\mathrm{CH}_{4}$ and the hydrophobic cavity of hemicryptophane was confirmed by a ${ }^{1} \mathrm{H}$ nuclear magnetic resonance (NMR) study. Six supramolecular complexes, including the two novel tris(2-pyridylmethyl)amine-based hemicryptophane complexes $\mathbf{C u}^{\mathrm{II}}$ (Hm-TPA) and $\mathbf{F e}^{\mathrm{II}}$ (Hm-TPA) (Scheme 1), displaying various first and second coordination spheres were immobilized onto silica and applied in the heterogeneous oxidation of $\mathrm{CH}_{4}$ in water by $\mathrm{H}_{2} \mathrm{O}_{2}$. We demonstrated that changing the nature of the second coordination sphere around the $\mathrm{V}=\mathrm{O}$ site could lead to improved efficiency or selectivity. Importantly, upon incorporation of a hemicryptophane hydrophobic cavity above a non-heme iron unit, both the efficiency and the selectivity for primary oxidation products $\mathrm{CH}_{3} \mathrm{OH}$ and $\mathrm{CH}_{3} \mathrm{OOH}$ were simultaneously enhanced. This work provides a proof of concept for the potential benefits of developing catalysts bearing a hydrophobic cavity above a bioinspired active center for the direct and clean transformation of $\mathrm{CH}_{4}$ to methanol.

\section{EXPERIMENTAL SECTION}

Preparation and Characterization of Metal Hemicryptophane Complexes. To evaluate the importance of the supramolecular structure to catalytic efficiency, several metal complexes bearing a hemicryptophane cavity and analogous complexes devoid of the cage were prepared. Complexes Cu' ${ }^{\text {II }}$ Hm-TREN), V(Hm-TKA), V(Hm-BINOL-TKA), and V(Bz-BINOL-TKA) (Scheme 1) were obtained according to previously reported procedures. ${ }^{19,20,22}$ In addition, the new complex $\mathrm{Cu}^{\mathrm{II}}(\mathrm{Hm}-\mathrm{TPA})\left(\mathrm{ClO}_{4}\right)_{2}$, based on the Hm-TPA hemicryptophane bearing a tris(2-pyridylmethyl)amine (TPA) moiety, ${ }^{23}$ was prepared (Scheme 1). The air-stable $\mathrm{Cu}^{\mathrm{II}}(\mathbf{H m}-\mathrm{TPA})\left(\mathrm{ClO}_{4}\right)_{2}$ complex was obtained by reacting $\mathrm{Hm}$-TPA with 1 equiv of copper(II) perchlorate at room 
temperature in acetone. The metalation occurred immediately, and the encaged complex was precipitated with diethyl ether, isolated by filtration, and characterized by ESI-HRMS (Figure S1), UV-vis (Figure S2), and EPR (Figure S3). In agreement with the simulated spectrum, the experimental EPR spectrum of $\mathrm{Cu}^{\mathrm{II}}(\mathrm{Hm}-\mathrm{TPA})\left(\mathrm{ClO}_{4}\right)_{2}$, in $\mathrm{CH}_{2} \mathrm{Cl}_{2}$, reveals the presence of two $\mathrm{Cu}(\mathrm{II})$-based species in solution, caused by two different tetragonal distortions. The first one, accounting for $15 \%$ of the global signal, corresponds to an elongated distortion $\left(\mathrm{d}_{x^{2}-y^{2}}\right)$, which is axial $\left(g=\left[\begin{array}{lll}2.270 & 2.090 & 2.090\end{array}\right]\right.$, and $a=\left[\begin{array}{lll}150 & 0 & 0\end{array}\right] \times$ $10^{-4} \mathrm{~cm}^{-1}$ ). The second one, accounting for $85 \%$ of the global signal, corresponds to a compressed distortion $\left(\mathrm{d}_{z}{ }^{2}\right)$, which is orthorhombic $\left(g=\left[\begin{array}{lll}2.244 & 2.120 & 1.987\end{array}\right]\right.$, and $a=\left[\begin{array}{lll}0 & 57 & 167\end{array}\right] \times$ $\left.10^{-4} \mathrm{~cm}^{-1}\right){ }^{24}$

After replacement of perchlorate anion with triflate, the complex $\mathbf{C u}$ (IIm-TPA) $\left(\mathrm{SO}_{3} \mathbf{C F}_{3}\right)_{2}$ afforded single crystals suitable for X-ray diffraction analysis (Figure 1). The structure

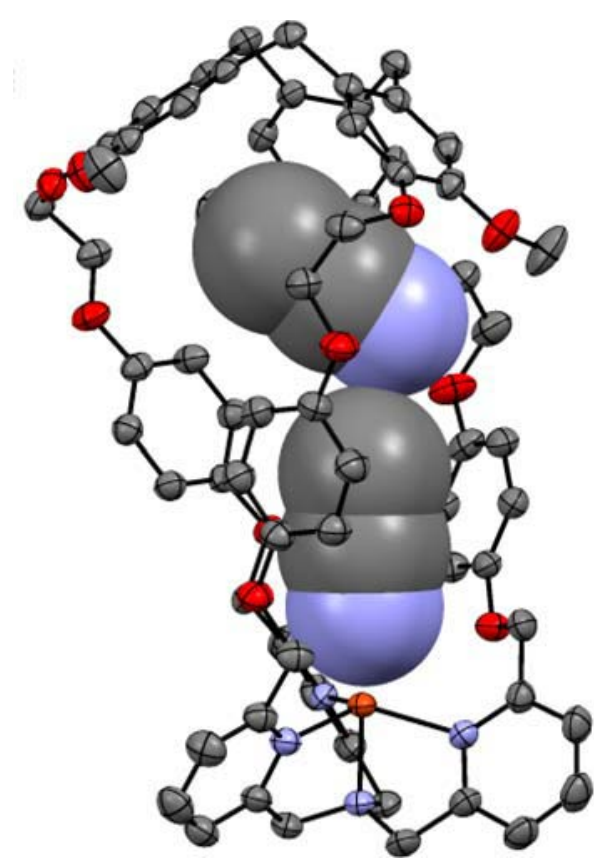

Figure 1. ORTEP (ellipsoids, 50\% probability) diagrams of the $\mathrm{X}$-ray crystal structure of $\left(\mathrm{CH}_{3} \mathrm{CN}\right)_{2} \subset \mathrm{Cu}$ II $(\mathrm{Hm}-\mathrm{TPA})\left(\mathrm{SO}_{3} \mathrm{CF}_{3}\right)_{2}$. Triflate counterions have been omitted for the sake of clarity.

of the caged complex shows one copper center that adopts a trigonal bipyramidal geometry, wherein the trigonal plane comprises the three pyridine nitrogen atoms $(\mathrm{N} 1-\mathrm{N} 3)$. The axial positions are occupied by the tertiary amine nitrogen (N4) and an acetonitrile molecule, which is pointing toward the inside of the Hm-TPA cavity. A well-defined cavity, encaging a second molecule of acetonitrile, is observed just above the copper center, attesting to an endohedral functionalization of the hemicryptophane, which simultaneously hosts the metal ion in its southern part (TPA unit) and one guest molecule $\left(\mathrm{CH}_{3} \mathrm{CN}\right)$ in its northern cavity (CTV unit).

The related iron complex $\mathrm{Fe}^{\mathrm{II}}(\mathrm{Hm}-\mathrm{TPA})\left(\mathrm{ClO}_{4}\right)_{2}$ was prepared by reacting $\mathrm{Hm}$-TPA with 1 equiv of iron(II) perchlorate at room temperature in acetonitrile. The metalation occurred immediately, and the encaged complex was precipitated with diethyl ether, isolated by filtration, and characterized by ESI-HRMS (Figure S4) and UV-vis (Figure
S5). The ${ }^{1} \mathrm{H}$ NMR spectra of the $\mathrm{Fe}^{\mathrm{II}}(\mathrm{Hm}-\mathrm{TPA})\left(\mathrm{SO}_{3} \mathbf{C F}_{3}\right)_{2}$ complex recorded in $\mathrm{CD}_{3} \mathrm{CN}$ at $298,270,260$, and $240 \mathrm{~K}$ exhibit downfield resonances when compared to those of the free ligand, attesting to a low-spin $\mathrm{Fe}$ (II) state in agreement with the reported ${ }^{1} \mathrm{H}$ NMR characterization of the model complex $\mathbf{F e}^{\mathrm{II}}$ (TPA) $\left(\mathbf{S O}_{3} \mathbf{C F}_{3}\right)_{2}$ (Figures $\mathrm{S} 6$ and $\left.\mathrm{S} 7\right) .^{25}$ Compared to those of the $\mathrm{C}_{3}$ symmetrical Hm-TPA ligand (Figure S6, top), the signals of $\mathrm{Fe}^{\mathrm{II}}(\mathrm{Hm}-\mathrm{TPA})\left(\mathrm{SO}_{3} \mathrm{CF}_{3}\right)_{2}$ appeared to be broader and splitted, indicating a loss of cage symmetry due to a metal center in an octahedral geometry (Figure S6, bottom) [expected for low-spin (LS) Fe(II) complexes]. This behavior differs from that of the model complex $\mathrm{Fe}^{\mathrm{II}}$ (TPA) $\left(\mathrm{SO}_{3} \mathrm{CF}_{3}\right)_{2}$, which displays an effective 3fold symmetry in solution due to the fast exchange process that averages the environment of the three pendant pyridines on the NMR time scale. ${ }^{25}$ Clearly, the more rigid supramolecular structure found in $\mathrm{Fe}^{\mathrm{II}}(\mathrm{Hm}-\mathrm{TPA})\left(\mathrm{SO}_{3} \mathrm{CF}_{3}\right)_{2}$ inhibits these fast exchange processes.

Encapsulation of Methane inside the Hemicryptophane Cavity. Cryptophanes are CTV-based homotopic capsules, which have been reported as efficient receptors for $\mathrm{CH}_{4}{ }^{26}$ On the other hand, a $\mathrm{C}_{3}$ symmetrical covalent molecular cage based on the TPA ligand has very recently been used by Badjic and co-workers for the trapping of small hydrophobic molecules, including $\mathrm{CH}_{2} \mathrm{Cl}_{2}$ and methane. ${ }^{27}$ The hemicryptophane $\mathrm{Hm}$-TPA is a heteroditopic derivative of cryptophane, built from a CTV unit (northern part) and a TPA ligand (southern part). We therefore investigated the ability of Hm-TPA to engage host-guest interaction with small hydrophobic substrates such as $\mathrm{CH}_{2} \mathrm{Cl}_{2}$ and $\mathrm{CH}_{4}$. Single crystals of $\mathrm{Hm}$-TPA, suitable for $\mathrm{X}$-ray diffraction, were obtained by slow diffusion of $\mathrm{Et}_{2} \mathrm{O}$ in a $\mathrm{CH}_{2} \mathrm{Cl}_{2}$ solution of the cage. Interestingly, the corresponding $\mathrm{XRD}$ structure reveals one encaged $\mathrm{CH}_{2} \mathrm{Cl}_{2}$ molecule, which appears to be wrapped by the $\mathrm{C}_{3}$ structure of Hm-TPA. This observation confirms the ability of the hydrophobic pocket of Hm-TPA to bind small hydrophobic guests in the solid state. We then investigated the interaction between $\mathrm{Hm}$-TPA and $\mathrm{CH}_{4}$ by ${ }^{1} \mathrm{H}$ NMR using $\mathrm{C}_{2} \mathrm{D}_{2} \mathrm{Cl}_{4}$ as the solvent. ${ }^{28}$ Upon methane bubbling, the signals of some aromatic protons of the CTV and TPA moieties of Hm-TPA display moderate high-field shifts (Figure $2 a$, signals $a-c, g$, and $h$ ), while aromatic protons corresponding to the phenyl spacers (Figure 2a, signals $\mathrm{e}$ and f) exhibit slightly more marked downfield shifts, attesting to the interaction of one (or more) molecule of $\mathrm{CH}_{4}$ with the host Hm-TPA (Table S1). Furthermore, the high-field shift $(1.92 \mathrm{~Hz})$ of the $\mathrm{CH}_{4}$ resonance observed in the presence of Hm-TPA (Figure 2d) is in good agreement with its encapsulation within the hemicryptophane cavity. It should be noted, however, that the observed shifts remain modest, indicating a weak interaction in $\mathrm{C}_{2} \mathrm{D}_{2} \mathrm{Cl}_{4}$, which might result from (i) a fast exchange process between bound and free $\mathrm{CH}_{4}$ molecules at $298 \mathrm{~K}$ or/and (ii) the competitive encapsulation of this hydrophobic solvent.

Oxidation of Methane. We then investigated the reactivity of different catalytic sites in the oxidation of methane. The influence of the metal $(\mathrm{Cu}, \mathrm{V}$, or $\mathrm{Fe})$, the first coordination sphere provided by the non-heme ligand, and the hemicryptophane structure was probed using the complexes shown in Scheme 1.

Methane, having very inert $\mathrm{C}-\mathrm{H}$ bonds with a bond dissociation energy (BDE) of $104.9 \mathrm{kcal} \mathrm{mol}^{-1}$, can be oxidized only by strong oxidizing species. When organic solvents 

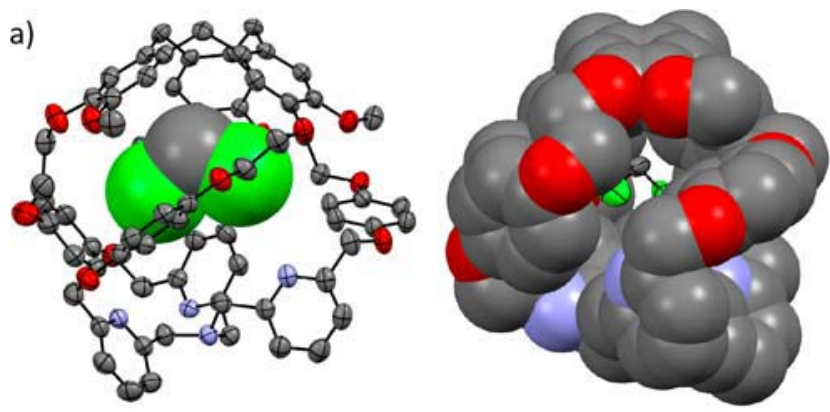

b)

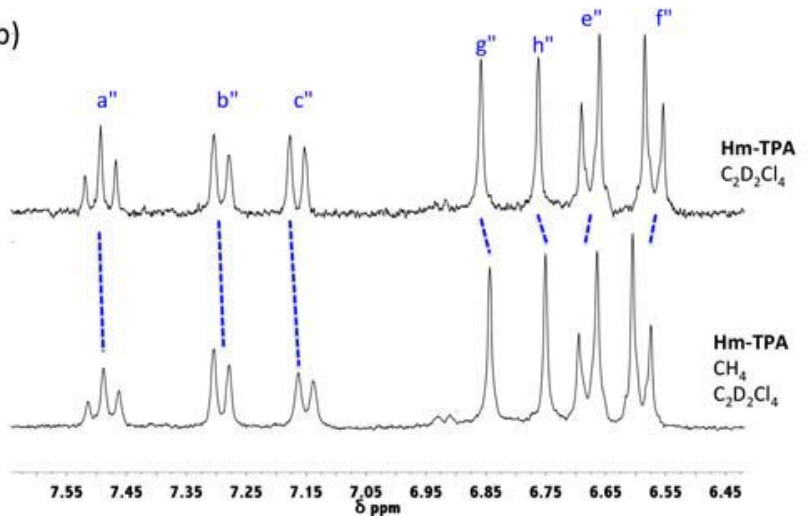

c)
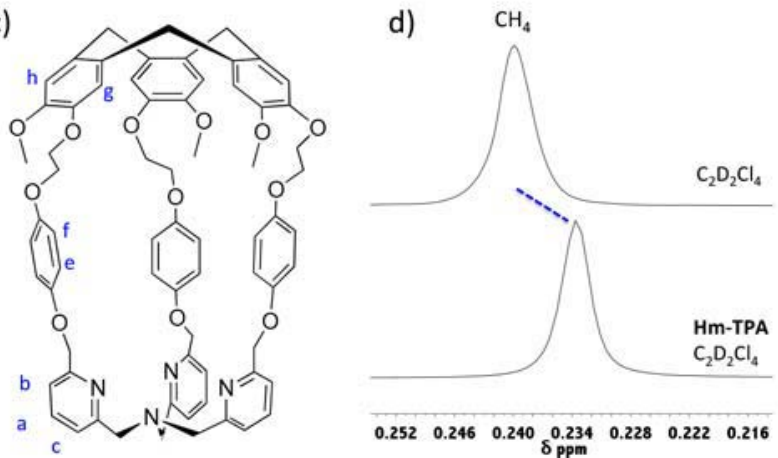

Figure 2. (a) Diagram of the X-ray crystal structure of $\mathbf{C H}_{2} \mathbf{C l}_{2} \subset$ Hm-TPA with space-filling representation of $\mathrm{CH}_{2} \mathrm{Cl}_{2}$ (left) and HmTPA (right). (b) Partial ${ }^{1} \mathrm{H}$ NMR spectra $\left(\mathrm{C}_{2} \mathrm{D}_{2} \mathrm{Cl}_{4}, 300 \mathrm{MHz}\right)$ of the cage $\mathrm{Hm}$-TPA at $298 \mathrm{~K}$ before (top) and after (bottom) bubbling of methane (3 equiv). (c) Schematic representation of the cage $\mathrm{Hm}$ TPA. (d) ${ }^{1} \mathrm{H}$ NMR resonance of $\mathrm{CH}_{4}$ in $\mathrm{C}_{2} \mathrm{D}_{2} \mathrm{Cl}_{4}$ in the absence (top) and presence (bottom) of Hm-TPA. typically containing more active $\mathrm{C}-\mathrm{H}$ bonds are used, e.g., $\mathrm{CH}_{3} \mathrm{CN}$ and $\mathrm{CH}_{2} \mathrm{Cl}_{2}$, their oxidation and the formation of $\mathrm{C}_{1}$ oxidation products cannot be excluded because the organic solvent is in a huge excess with respect to dissolved $\mathrm{CH}_{4}$, typically in the millimolar concentration range. To avoid possible oxidation of organic solvents by the metal-based oxidizing species that would mask the target reaction, the oxidation of $\mathrm{CH}_{4}$ was studied in water. To this end, the complexes were supported on silica and applied in heterogeneous oxidation of methane by $\mathrm{H}_{2} \mathrm{O}_{2}$, a clean and industrially relevant oxidant. It is noteworthy that this oxidant can also be used by monooxygenases for the generation of active highvalence metal-oxo species via shunted pathways. The reactions were performed in slightly acidic water $(0.07 \mathrm{M}$ $\mathrm{H}_{2} \mathrm{SO}_{4}$ ) for $20 \mathrm{~h}$ at $60{ }^{\circ} \mathrm{C}$ using an autoclave containing $50 \mathrm{mg}$ of a $\mathrm{SiO}_{2}$-supported catalyst $(1 \mu \mathrm{mol}$ of complex $)$ and $0.33 \mathrm{M}$ $\mathrm{H}_{2} \mathrm{O}_{2}$ oxidant, and the mixtures charged with methane (30 bar). ${ }^{29}$ The catalytic performances of "encaged" and "naked" catalysts were evaluated by the direct comparison of (i) the selectivity for primary oxidation products (percentage of $\mathrm{CH}_{3} \mathrm{OH}$ and $\mathrm{CH}_{3} \mathrm{OOH}$ produced with respect to the total amount of oxidized products) and (ii) the turnover number (TON, micromoles of oxidation products per micromole of catalyst).

\section{RESULTS}

Copper Complexes. In the initial experiments, the tris (2aminoethyl)amine (TREN) copper-based supramolecular complex $\mathbf{C u}$ II $(\mathbf{H m}-\mathrm{TREN})\left(\mathrm{ClO}_{4}^{-}\right)_{2}$ and its "naked" analogue $\mathbf{C u}^{\text {II }}$ (TREN) $\left(\mathbf{C l O}_{4}^{-}\right)_{2}$ (Scheme 1) were compared in the heterogeneous oxidation of $\mathrm{CH}_{4}$ by $\mathrm{H}_{2} \mathrm{O}_{2}$. The positioning of the hemicryptophane hydrophobic cavity above the $\mathrm{Cu}^{\mathrm{II}}$-based active site of $\mathrm{Cu}^{\mathrm{II}}(\mathrm{Hm}$-TREN $)\left(\mathrm{ClO}_{4}^{-}\right)_{2}$ has recently been described as an efficient strategy for enhancing the activity and selectivity of cyclohexane oxidation. Higher product yields and an increase in the selectivity for cyclohexanol were observed. ${ }^{19}$ This improvement originates from the positive conjunction of two factors. (i) The supramolecular architecture better protects the catalyst from oxidative degradation because another catalyst molecule cannot fit inside the hemicryptophane cavity and access the active species, and (ii) the affinity of the hemicryptophane host for hydrophobic cyclohexane is higher than that of the more hydrophilic cyclohexanol. However, when applied to the oxidation of $\mathrm{CH}_{4}$, caged $\mathrm{Cu}^{\mathrm{II}}(\mathrm{Hm}-\mathrm{TREN})\left(\mathrm{ClO}_{4}^{-}\right)_{2}$ and "naked" $\mathrm{Cu}^{\mathrm{II}}(\mathrm{TREN})$ $\left(\mathrm{ClO}_{4}^{-}\right)_{2}$ display low TONs of 1.8 and 0.6 , respectively,

Table 1. Oxidation of $\mathrm{CH}_{4}$ by $\mathrm{H}_{2} \mathrm{O}_{2}$ Catalyzed by Supported Copper(II) Complexes ${ }^{a}$

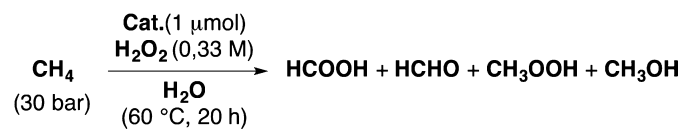

\begin{tabular}{|c|c|c|c|c|c|}
\hline catalyst & $\mathrm{HCOOH}^{b} \mathrm{TON}$ & $\mathrm{HCHO}^{c} \mathrm{TON}$ & $\mathrm{CH}_{3} \mathrm{OOH}^{b} \mathrm{TON}$ & $\mathrm{CH}_{3} \mathrm{OH}^{b} \mathrm{TON}$ & total $^{d}$ TON \\
\hline $\mathrm{Cu}^{\mathrm{II}}(\mathrm{TREN})$ & 0.5 & - & 0.1 & - & 0.6 \\
\hline $\mathrm{Cu}^{\mathrm{II}}(\mathrm{Hm}-\mathrm{TREN})$ & 1.3 & 0.2 & - & 0.3 & 1.8 \\
\hline $\mathrm{Cu}^{\mathrm{II}}(\mathrm{Hm}-\mathrm{TPA})$ & 1.4 & 0.1 & - & - & 1.5 \\
\hline $\mathrm{Cu}^{\mathrm{II}}\left(\mathrm{Hm}-\mathrm{TREN}-\mathrm{COO}^{-}\right)$ & 0.7 & - & - & - & 0.7 \\
\hline
\end{tabular}

${ }^{a}$ Reaction conditions: reaction time of $20 \mathrm{~h}, 60{ }^{\circ} \mathrm{C}$, solvent of $\mathrm{H}_{2} \mathrm{O}, 2 \mathrm{~mL} ; 0.33 \mathrm{M} \mathrm{H}_{2} \mathrm{O}_{2}, 0.07 \mathrm{M} \mathrm{H}_{2} \mathrm{SO}_{4}, P_{\mathrm{CH}_{4}}=30$ bar, $50 \mathrm{mg}$ of silica-supported catalyst containing $1.0 \mu \mathrm{mol}$ of complex. ${ }^{b} \mathrm{TONs}$ of $\mathrm{CH}_{3} \mathrm{OH}, \mathrm{CH}_{3} \mathrm{OOH}$, and $\mathrm{HCOOH}$ were determined by ${ }^{1} \mathrm{H}$ NMR and are the average of at least three experiments. ${ }^{c}$ The yield of $\mathrm{HCHO}$ was determined by the Nash colorimetric method. ${ }^{d}$ Moles of $\left(\mathrm{CH}_{3} \mathrm{OH}+\mathrm{CH}_{3} \mathrm{OOH}+\mathrm{HCOOH}+\right.$ $\mathrm{HCHO}) /$ moles of catalyst. The estimated error for the TON was $\pm 20 \%$. 
indicating the difficulty of reaching an efficient $\mathrm{CH}_{4}$ oxidation using the TREN-Cu ${ }^{\text {II }}$ active site in combination with $\mathrm{H}_{2} \mathrm{O}_{2}$ (Table 1). Nevertheless, the supramolecular complex Cu${ }^{\mathrm{II}}(\mathrm{Hm}$-TREN $)\left(\mathrm{ClO}_{4}^{-}\right)_{2}$ provided a TON 3-fold higher than that of "naked" $\mathbf{C u}^{\mathbf{I I}}(\mathbf{T R E N})\left(\mathbf{C l O}_{4}{ }^{-}\right)_{2}$ (Table 1). This positive confinement effect is in line with the results obtained in the cyclohexane oxidation. ${ }^{19}$ Unfortunately, the low yields of oxidized products preclude the direct comparison of the selectivity of these complexes for $\mathrm{CH}_{3} \mathrm{OH}$ and $\mathrm{CH}_{3} \mathrm{OOH}$. Similarly, the $\mathbf{C u}$ II $(\mathbf{H m}-\mathbf{T P A})\left(\mathbf{C l O}_{4}\right)_{2}$ complex showed a low activity in methane oxidation ( $\mathrm{TON}=1.5)$.

Thus, no significant changes in reactivity were observed upon replacement of the three amine functions of the TREN ligand with the more withdrawing pyridine units. The related water-soluble cage complex $\mathbf{C u}{ }^{\mathrm{II}}\left(\mathrm{Hm}-\mathrm{TREN}_{-} \mathbf{C O O}^{-}\right)$, an analogue of $\mathrm{Cu}^{\mathrm{II}}(\mathbf{H m}-\mathrm{TREN})$ in which the methoxy groups of the CTV moiety are replaced by three carboxylate groups, was then studied as a homogeneous catalyst. When applied under identical catalytic conditions, but in a homogeneous fashion, $\mathbf{C u}^{\text {II }}\left(\mathbf{H m}-\mathbf{T R E N}-\mathbf{C O O}^{-}\right)$displays a catalytic efficiency that is lower than that of its silica supported counterpart, CuII (Hm-TREN), with total TONs of 0.7 and 1.8, respectively (Table 1). These results confirm that the higher catalytic efficiency observed for the silica-supported catalyst cannot arise from a leaching of the catalyst from the silica. The sluggish oxidation of $\mathrm{CH}_{4}$ mediated by catalytic amounts of $\mathrm{Cu}^{\mathrm{II}}(\mathrm{TREN})\left(\mathrm{ClO}_{4}\right)_{2}, \mathrm{Cu}^{\mathrm{II}}(\mathrm{Hm}-\mathrm{TREN})\left(\mathrm{ClO}_{4}\right)_{2}$, and $\mathrm{Cu}^{\mathrm{II}}(\mathbf{H m}-\mathrm{TPA})\left(\mathrm{ClO}_{4}\right)_{2}$ might be explained by the nature of the active site. Although the involvement of the $\mathrm{Cu}$ (III) oxidation state in biological and biomimetic oxidation processes has been documented, ${ }^{30}$ the activation of $\mathrm{H}_{2} \mathrm{O}_{2}$ at $\mathrm{Cu}(\mathrm{II})$ centers can lead to the generation of $\mathrm{HOO}^{\bullet}$ and $\mathrm{HO}^{\bullet}$ radicals in a Fenton-like fashion. ${ }^{31}$ Therefore, in the presence of a recalcitrant methane molecule, the freely diffusing $\mathrm{HOO}^{\bullet}$ or/and $\mathrm{HO}^{\bullet}$ species might react preferentially with the weaker $\mathrm{C}-\mathrm{H}$ bonds found in the hemicryptophane scaffold, resulting in the degradation of the complexes. This hypothesis was confirmed by ESI-MS analysis of the $\mathrm{Cu}^{\mathrm{II}}(\mathbf{H m}-\mathrm{TPA})$ solution in $\mathrm{CH}_{3} \mathrm{CN}$ after addition of $\mathrm{H}_{2} \mathrm{O}_{2}$, where signals with $\mathrm{m} / z$ values corresponding to the oxidized complex were observed (Figure S8).

Vanadium Complexes. Oxido-vanadium(V) hemicryptophane complexes bearing a trialkanol amine coordination unit (TKA) have recently been described as efficient catalysts for sulfoxidation reactions. ${ }^{20,22}$ Indeed, supramolecular $\mathrm{V}(\mathrm{V})$ based complexes V(Hm-TKA) and V(Hm-BINOL-TKA) have shown enhanced selectivity, reactivity, and turnover numbers compared to those of their related model complex V(TKA) that is devoid of the cavity. This strong confinement effect, derived from the hydrophobic cavity present in these flexible systems, allows for both hydrophobic substrate recognition and hydrophilic product release. On this basis, we have first focused on exploring the ability of oxidovanadium supramolecular complexes to oxidize methane. The importance of having a second coordination sphere is well emphasized by comparing the supramolecular catalyst $\mathrm{V}(\mathbf{H m}$ TKA) and its "naked" analogue V(TKA) (Figure 3 and Table S1). The introduction of a hydrophobic cavity above the metal site leads to an increase in the yield of $\mathrm{CH}_{3} \mathrm{OH}$ and $\mathrm{CH}_{3} \mathrm{OOH}$ (Table 2). Importantly, similar TONs of 6.6 and 7.4 were found using V(Hm-TKA) and V(TKA), respectively, indicating that the caged catalyst did not suffer from undesired product inhibition, which is commonly observed for supra-
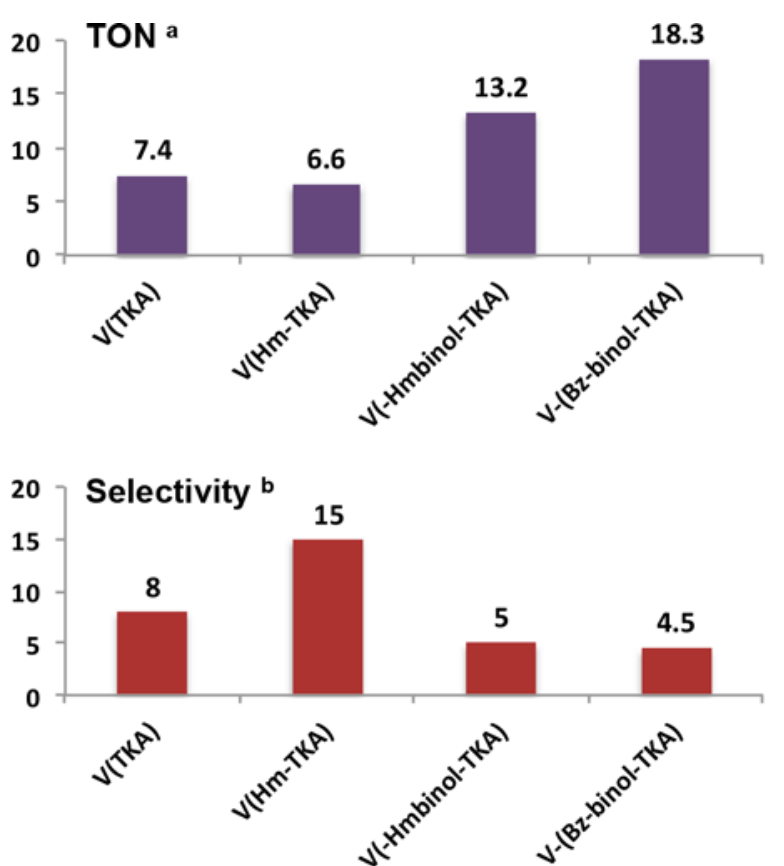

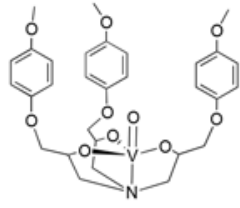

$\mathrm{V}$ (TKA)

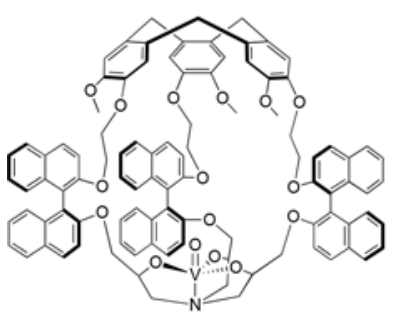

V(Hm-BINOL-TKA)

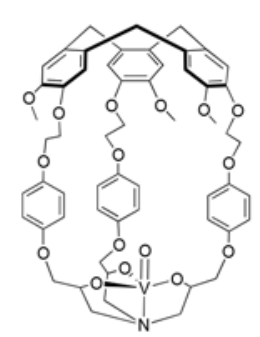

V(Hm-TKA)

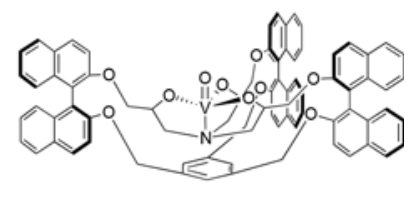

V(Bz-BINOL-TKA $)$
Figure 3. Structures of oxido-vanadium complexes and comparison of their TONs and selectivities to those of the initial oxidation products of methane. Footnote a: moles of $\left(\mathrm{CH}_{3} \mathrm{OH}+\mathrm{CH}_{3} \mathrm{OOH}+\right.$ $\mathrm{HCOOH}+\mathrm{HCHO}) /$ moles of catalyst. Footnote b: $\left(\mathrm{CH}_{3} \mathrm{OH}+\right.$ $\left.\mathrm{CH}_{3} \mathrm{OOH}\right) /\left(\mathrm{CH}_{3} \mathrm{OH}+\mathrm{CH}_{3} \mathrm{OOH}+\mathrm{HCOOH}+\mathrm{HCHO}\right) \times 100$. For reaction conditions, see Table 1.

molecular systems. A shorter reaction time $(6 \mathrm{~h})$ resulted in a TON of 1.9 for $\mathbf{V}(\mathbf{H m}$-TKA). The supramolecular catalyst V(Hm-BINOL-TKA), an analogue of V(Hm-TKA) in which the phenyl spacers are replaced by biphenyl groups, displays an improved catalytic efficiency ( 2 times higher) compared to that of $\mathbf{V}(\mathbf{H m}$-TKA) (Figure 3). Such a behavior is consistent with a previous study of the sulfoxidation reaction in which $\mathrm{V}(\mathrm{Hm}$ BINOL-TKA) was found to be $\sim 5$ times more efficient than $\mathbf{V}$ (Hm-TKA $){ }^{20}$ However, this improvement in TON was accompanied by an undesired decrease in the selectivity in $\mathrm{CH}_{3} \mathrm{OH}$ and $\mathrm{CH}_{3} \mathrm{OOH}$, which dropped from $15 \%$ to $5 \%$ when passing from $\mathbf{V}$ (Hm-TKA) to $\mathbf{V}$ (Hm-BINOL-TKA) (Figure 3). Therefore, the nature, size, and shape of the hydrophobic 
Table 2. Oxidation of $\mathrm{CH}_{4}$ by $\mathrm{H}_{2} \mathrm{O}_{2}$-Supported Vanadium Complexes ${ }^{a}$

\begin{tabular}{|c|c|c|c|c|c|}
\hline Catalyst & $\mathrm{HCOOH}^{\mathrm{a}}$ TON & $\mathrm{HCHO}^{\mathbf{b}}$ TON & $\mathrm{CH}_{3} \mathrm{OOH}^{\mathrm{a}} \mathrm{TON}$ & $\mathrm{CH}_{3} \mathrm{OH}^{\mathrm{a}} \mathrm{TON}$ & total $^{\mathrm{c}}$ TON \\
\hline $\mathrm{V}$ (TKA) & 6.6 & 0.2 & 0.3 & 0.3 & 7.4 \\
\hline V(Hm-TKA) & 4.8 & 0.8 & 1 & - & 6.6 \\
\hline V(Hm-BINOL-TKA) & 10.1 & 2.4 & - & 0.7 & 13.2 \\
\hline V(Bz-BINOL_TKA) & 13.8 & 3.7 & - & 0.8 & 18.3 \\
\hline
\end{tabular}

cavity clearly impact the reaction outcome of $\mathrm{CH}_{4}$ oxidation at the oxido-vanadium catalytic sites. This trend was further confirmed by studying the catalyst V(Bz-BINOL-TKA) having a bowl-shaped supramolecular structure. V(Bz-BINOL-TKA) was previously reported as a particularly efficient sulfoxidation catalyst due to its bowl-shaped hydrophobic pocket. ${ }^{22}$ When $\mathbf{V}(\mathbf{B z}-\mathrm{BINOL}-\mathrm{TKA})$ was applied to the oxidation of $\mathrm{CH}_{4}$, a TON of 18.3 was obtained. This TON value is significantly higher than those obtained with $\mathbf{V}(\mathbf{H m}$-TKA) and $\mathrm{V}(\mathbf{H m}-$ BINOL-TKA). As expected, the selectivity in $\mathrm{CH}_{3} \mathrm{OH}$ and $\mathrm{CH}_{3} \mathrm{OOH}$ drastically dropped for this open structure [3.3 times lower than that of $\mathbf{V}(\mathbf{H m}-\mathbf{T K A})]$, confirming the crucial role of endohedral functionalization (Figure 3 and Table 2).

Altogether, these results reveal that the oxidation of $\mathrm{CH}_{4}$ can be tuned by controlling the second coordination sphere of oxido-vanadium complexes. Depending on the supramolecular architecture, either selectivity or catalytic efficiency can be improved but no simultaneous enhancement of both efficiency and selectivity could be observed.

Iron Complexes. The well-documented activation of $\mathrm{H}_{2} \mathrm{O}_{2}$ by non-heme iron(II) complexes leads to the formation of hydroperoxo-iron(III) $\mathrm{Fe}-\mathrm{OOH}$ and oxo-iron(IV) $\mathrm{Fe}=\mathrm{O}$ (under acidic conditions) metal-based oxidants. ${ }^{32}$ Alternatively, simple iron salts can catalyze the oxidation of the strong $\mathrm{C}-\mathrm{H}$ bonds via generation of hydroxyl radicals from $\mathrm{H}_{2} \mathrm{O}_{2}$. ${ }^{33}$ The formation of a well-defined metal-based oxidant inside the hydrophobic cavity might lead to an oxidation reaction oriented toward the substrate $\mathrm{C}-\mathrm{H}$ bonds rather than on the $\mathrm{C}-\mathrm{H}$ bonds of the side arms of the ligand suprastructure. Indeed, the catalytic oxidation of $\mathrm{CH}_{4}$ mediated by $\mathrm{Fe}^{\mathrm{II}}(\mathbf{H m}$ TPA) $\left(\mathrm{ClO}_{4}\right)_{2}$ was found to be significantly more efficient than that of its copper(II) counterpart with a higher TON of 9.2 compared to a TON of 1.5 (Tables 1 and 3). A shorter reaction time $(6 \mathrm{~h})$ resulted in a TON of 2.8 . It is noteworthy

Table 3. Oxidation of $\mathrm{CH}_{4}$ by $\mathrm{H}_{2} \mathrm{O}_{2}$ Catalyzed by the Supported Iron-Based Complexes ${ }^{a}$

\begin{tabular}{|c|c|c|c|c|c|}
\hline \multirow{2}{*}{$\begin{array}{c}\mathbf{C H}_{\mathbf{4}} \\
\text { (30 Bars) }\end{array}$} & $\begin{array}{c}\text { Cat. }(1 \mu \mathrm{mol}) \\
\mathrm{H}_{2} \mathrm{O}_{2}(0.33 \mathrm{M})\end{array}$ & \multicolumn{4}{|c|}{$\mathrm{HCOOH}+\mathrm{HCHO}+\mathrm{CH}_{3} \mathrm{OOH}+\mathrm{CH}_{3} \mathrm{OH}$} \\
\hline & $\left(60^{\circ} \mathrm{C}, 20 \mathrm{~h}\right)$ & & & & \\
\hline catalyst & $\begin{array}{c}\mathrm{HCOOH}^{b} \\
\text { TON }\end{array}$ & $\begin{array}{c}\mathrm{HCHO}^{c} \\
\text { TON }\end{array}$ & $\begin{array}{c}\mathrm{CH}_{3} \mathrm{OOH}^{b} \\
\text { TON }\end{array}$ & $\begin{array}{c}\mathrm{CH}_{3} \mathrm{OH}^{b} \\
\text { TON }\end{array}$ & $\begin{array}{l}\text { total }^{d} \\
\text { TON }\end{array}$ \\
\hline II (TPA) & 1.7 & 2.3 & 0.7 & - & 4.7 \\
\hline II $(\mathrm{Hm}-$ & 4.7 & 2.0 & 1.4 & 1.1 & 9.2 \\
\hline
\end{tabular}

${ }^{a}$ Reaction conditions: reaction time of $20 \mathrm{~h}, 60{ }^{\circ} \mathrm{C}$, solvent of $\mathrm{H}_{2} \mathrm{O}(2$ $\mathrm{mL}), 0.33 \mathrm{M} \mathrm{H}_{2} \mathrm{O}_{2}, P_{\mathrm{CH}_{4}}=30 \mathrm{bar}, 50 \mathrm{mg}$ of silica-supported catalyst containing $1.0 \mu \mathrm{mol}$ of complex. ${ }^{b} \mathrm{TONs}$ of $\mathrm{CH}_{3} \mathrm{OH}, \mathrm{CH}_{3} \mathrm{OOH}$, and $\mathrm{HCOOH}$ were determined by ${ }^{1} \mathrm{H}$ NMR and are the average of at least three experiments. ${ }^{c}$ The yield of $\mathrm{HCHO}$ was determined by the Nash colorimetric method. ${ }^{d}$ Moles of $\left(\mathrm{CH}_{3} \mathrm{OH}+\mathrm{CH}_{3} \mathrm{OOH}+\mathrm{HCOOH}+\right.$ $\mathrm{HCHO}) /$ moles of catalyst. that the efficiency of the supramolecular complex was also 2 times higher than that of the model complex $\mathrm{Fe}^{\mathrm{II}}(\mathbf{T P A})$ $\left(\mathrm{ClO}_{4}\right)_{2}$ that is devoid of a cavity $[\mathrm{TON}=4.7$ (Table 3$\left.)\right]$.

Although the absolute yields of the over-oxidized products formaldehyde and formic acid appear to be enhanced by a factor of 1.7 when the supramolecular catalyst was used $\left[\mathrm{TON}_{\mathrm{HCHO}+\mathrm{HCOOH}}=4\right.$ and 6.7 for $\mathbf{F e}^{\mathrm{II}}$ (TPA) and $\mathrm{Fe}^{\mathrm{II}}(\mathrm{HmTPA})$, respectively], these values are not indicative of the reaction selectivity. Indeed, the selectivity toward the primary product was determined by looking at the ratio of mono-oxidized $\left(\mathrm{CH}_{3} \mathrm{COOH}\right.$ and $\left.\mathrm{CH}_{3} \mathrm{OH}\right)$ to over-oxidized ( $\mathrm{HCOOH}$ and $\mathrm{HCHO}$ ) products (see Figure 4). The analysis of the oxidation products revealed a 2 -fold enhanced selectivity toward $\mathrm{CH}_{3} \mathrm{OH}$ and $\mathrm{CH}_{3} \mathrm{OOH}$ for the caged catalyst

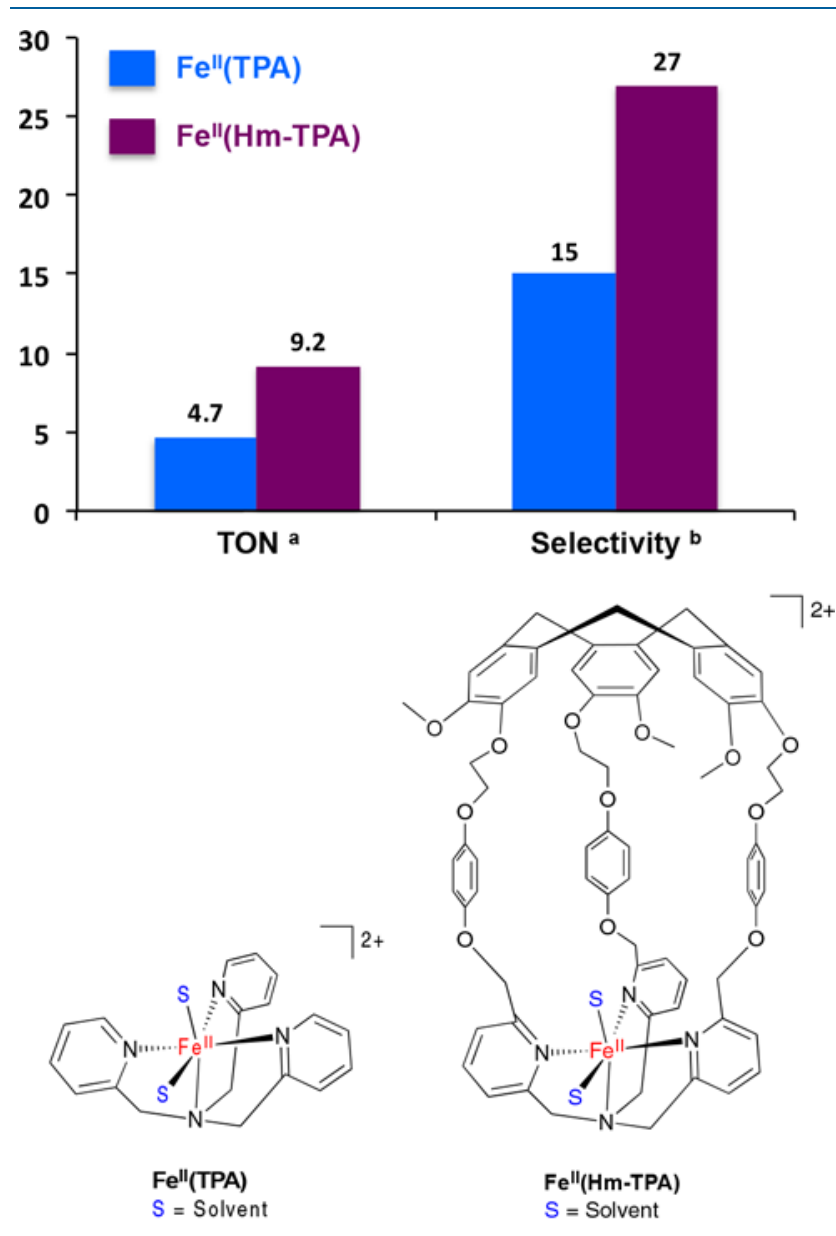

Figure 4. Comparison of TON and selectivity toward primary products of methane oxidation for iron catalysts $\mathrm{Fe}^{\mathrm{II}}(\mathrm{Hm}-\mathrm{TPA})$ $\left(\mathrm{ClO}_{4}\right)_{2}$ and $\mathrm{Fe}^{\mathrm{II}}(\mathrm{TPA})\left(\mathrm{ClO}_{4}\right)_{2}$. Footnote a: moles of $\left(\mathrm{CH}_{3} \mathrm{OH}+\right.$ $\left.\mathrm{CH}_{3} \mathrm{OOH}+\mathrm{HCOOH}+\mathrm{HCHO}\right) /$ moles of catalyst. Footnote b: $\left(\mathrm{CH}_{3} \mathrm{OH}+\mathrm{CH}_{3} \mathrm{OOH}\right) /\left(\mathrm{CH}_{3} \mathrm{OH}+\mathrm{CH}_{3} \mathrm{OOH}+\mathrm{HCOOH}+\right.$ $\mathrm{HCHO}) \times 100$. For reaction conditions, see Table 1 . 
$\mathrm{Fe}^{\mathrm{II}}(\mathrm{Hm}-\mathrm{TPA})\left(\mathrm{ClO}_{4}\right)_{2}(27 \%$ selectivity $)$ compared to that of the "naked" complex $\mathrm{Fe}^{\mathrm{II}}(\mathrm{TPA})\left(\mathrm{ClO}_{4}\right)_{2}$ (15\% selectivity). This selectivity in primary oxidation products was the highest observed among all bioinspired complexes screened during this study. Thus, the oxidation of $\mathrm{CH}_{4}$ mediated by $\mathrm{Fe}^{\mathrm{II}}(\mathbf{H m}$ TPA) $\left(\mathrm{ClO}_{4}\right)_{2}$ was reinforced by a strong confinement effect. The incorporation of the hydrophobic cavity above the TPAiron(II) active center enhances the yield of mono-oxidized

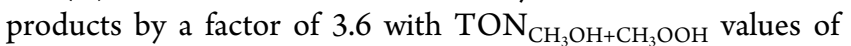
2.5 and 0.7 for $\mathrm{Fe}^{\mathrm{II}}(\mathrm{Hm}-\mathrm{TPA})\left(\mathrm{ClO}_{4}\right)_{2}$ and $\mathrm{Fe}^{\mathrm{II}}$ (TPA)$\left(\mathrm{ClO}_{4}\right)_{2}$, respectively (Figure 4 and Table 3). Such a confinement effect can be explained by the existence of host-guest interaction between $\mathrm{CH}_{4}$ and the hemicryptophane hydrophobic cavity, leading to (i) proximity between the substrate and active site and (ii) release of the hydrophilic oxidized products $\left(\mathrm{CH}_{3} \mathrm{OH}\right.$ and $\left.\mathrm{CH}_{3} \mathrm{OOH}\right)$ from the hemicryptophane hydrophobic cage. Importantly, similar behaviors are reported for the oxidation of cyclohexane, ${ }^{19}$ and thioanisole, ${ }^{20}$ inside the hydrophobic cavity of hemicryptophane-based catalysts.

\section{DISCUSSION}

In this study, a novel strategy for the development of bioinspired catalysts for the oxidation of methane to methanol was proposed and evaluated. To combine a reactive metal catalytic site with an adjacent hydrophobic pocket for methane binding, a series of iron, vanadium, and copper complexes supported by trialkanolamine, tren, and tris(2-pyridylmethyl) amine ligands bearing hemicryptophane moieties was prepared. The interaction of methane with hydrophobic cages of Hm-TPA was observed by the ${ }^{1} \mathrm{H}$ NMR method. We have shown that the positioning of a hemicryptophane hydrophobic cavity above a metal-based oxidizing center positively influences the way that methane $\mathrm{C}-\mathrm{H}$ bonds are catalytically oxidized by $\mathrm{H}_{2} \mathrm{O}_{2}$. Indeed, the functional duality of the hemicryptophane structure allows for host-guest interactions with hydrophobic substrates inside its well-defined cavity (northern part), along with the simultaneous coordination of biologically relevant $\mathrm{V}^{\mathrm{V}}, \mathrm{Cu}^{\mathrm{II}}$, and $\mathrm{Fe}^{\mathrm{II}}$ metal ions (southern part). The heterogeneous catalytic oxidation of methane in water has been studied through the screening of six vanadium-, copper-, and iron-based silica-supported complexes bearing a supramolecular second coordination sphere. Although the cage compounds could not be recycled because of progressive decomposition during the reaction [as observed for the $\mathbf{C u}^{\mathrm{II}}(\mathbf{H m}-\mathbf{T P A}$ ) complex (Figure S8)], the effect of confinement on $\mathrm{CH}_{4}$ oxidation has been unambiguously shown through the direct comparison between "encaged" and "naked" complexes. Such catalyst breakdown accompanied by the known decomposition of $\mathrm{H}_{2} \mathrm{O}_{2}$ into $\mathrm{H}_{2} \mathrm{O}$ and $\mathrm{O}_{2}$ leads to undesired $\mathrm{H}_{2} \mathrm{O}_{2}$ consumption that justifies the elevated amounts of $\mathrm{H}_{2} \mathrm{O}_{2}$ required to convert methane in our catalytic systems. Although copper-based complexes were found to be rather sluggish catalysts, their iron(II) and vanadium(V) analogues display promising catalytic efficiencies with total TONs ranging from 4.7 to 18.3 . It was found that the supramolecular complexes simultaneously holding an oxidovanadium active center, binaphthyl spacers, and either CTV (hydrophobic cavity, Hm-BINOL-TKA) or a benzene unit (open hydrophobic pocket, Bz-BINOL-TKA) were the most efficient catalysts with total TONs of 13.2 and 18.3, respectively. However, these improved catalytic efficiencies were associated with an undesired decrease in selectivity toward initial oxidation products. Thus, it appears that in these cases the molecular cage catalysts show a higher efficiency also favoring the over-oxidation of methane, as supported by the TON in over-oxidation products. This highlights how challenging it is to develop catalytic systems featuring both high activity and selectivity in methane oxidation. On the other hand, the confinement effect observed for hemicryptophane complex V(Hm-TKA) (where binaphthyl spacers are replaced by phenyl moieties) results in improved selectivity, while its catalytic efficiency remains similar to that of its parent model complex. Remarkably, controlling the microenvironment above a non-heme iron(II)(TPA) active site clearly improves both the efficiency and the selectivity of the catalytic oxidation of $\mathrm{CH}_{4}$. The intrinsic inertness of methane compared to its mono-oxidized analogues (such as methanol) makes the single oxidation of $\mathrm{CH}_{4}$ a particularly challenging task. Athough formic acid is the major product with all of the cage complexes tested, a strong improvement in selectivity is observed using the new supramolecular catalyst $\mathrm{Fe}^{\mathrm{II}}(\mathbf{H m}-\mathbf{T P A})$. Indeed, the yield in target mono-oxidized products $\left(\mathrm{CH}_{3} \mathrm{OH}\right.$ and $\mathrm{CH}_{3} \mathrm{OOH}$ ) was successfully increased (by 3.6-fold) compared to that of its "naked" model. We propose that such a confinement effect arises from the encapsulation of $\mathrm{CH}_{4}$ within the organic hydrophobic cavity located above the iron(II) catalytic center, along with the release of the more hydrophilic mono-oxidized products to the bulk solution. To the best of our knowledge, this represents the first example of methane oxidation catalyzed by well-defined bioinspired catalysts inside the cavity of a molecular receptor.

\section{CONCLUSION}

The results obtained in this study highlight the relevance of the hemicryptophane nanoreactors, which can be used as homogeneous or heterogeneous supported catalysts. These functional models combine the efficiency of heterogeneous catalysis (in pure water) with the convenient character of homogeneous systems (host-guest studies). Therefore, the confinement of well-defined metal-based active centers that can activate the green and cheap $\mathrm{H}_{2} \mathrm{O}_{2}$ oxidant should be considered as a promising strategy for the further development of highly active catalysts for the selective oxidation of methane to methanol. Finally, in contrast to sluggish copper(II) complexes, the encouraging results obtained with the iron(II)-based catalysts might account for the involvement of a high-valence metal-based oxidant in a manner similar to that involved for enzymatic systems (MMO). Future work will be focused on the preparation of a catalyst with improved oxidizing activity and stability. 
(1) Schwach, P.; Pan, X.; Bao, X. Direct conversion of methane to value-added chemicals over heterogeneous catalysts: challenges and prospects. Chem. Rev. 2017, 117, 8497-8520.

(2) Kondratenko, E. V.; Peppel, T.; Seeburg, D.; Kondratenko, V. A.; Kalevaru, N.; Martin, A.; Wohlrab, S. Methane conversion into different hydrocarbons or oxygenates: current status and future perspectives in catalyst development and reactor operation. Catal. Sci. Technol. 2017, 7, 366-381.

(3) Sazinsky, M. H.; Lippard, S. J. Methane Monooxygenase: functionalizing methane at iron and copper. Met. Ions Life Sci. 2015, $15,205-256$.

(4) Wang, V. C.-C.; Maji, S.; Chen, P. P.-Y.; Lee, H. K.; Yu, S. S.-F.; Chan, S. I. Alkane oxidation: methane monooxygenases: related enzymes, and their biomimetics. Chem. Rev. 2017, 117, 8574-8621.

(5) (a) Merkx, M.; Kopp, D. A.; Sazinsky, M. H.; Blazyk, J. L.; Müller, J.; Lippard, S. J. Dioxygen Activation and Methane Hydroxylation by Soluble Methane Monooxygenase: A Tale of Two Irons and Three Proteins. Angew. Chem., Int. Ed. 2001, 40, 2782 2807. (b) Baik, M.-H.; Newcomb, M.; Friesner, R. A.; Lippard, S. J. Mechanistic Studies on the Hydroxylation of Methane by MethaneMonooxygenase. Chem. Rev. 2003, 103, 2385-2420.

(6) Lawton, T. J.; Rosenzweig, A. C. Methane-oxidizing enzymes: an upstream problem in biological gas-to-liquids conversion. J. Am. Chem. Soc. 2016, 138, 9327-9340.

(7) Ross, M. O.; Rosenzweig, A. C. A tale of two methane monooxygenases. JBIC, J. Biol. Inorg. Chem. 2017, 22, 307-319.

(8) Lee, S. J.; McCormick, M. S.; Lippard, S. J.; Cho, U. S. Control of substrate access to the active site in methane monooxygenase. Nature 2013, 494, 380-384.

(9) Tshuva, E. Y.; Lippard, S. J. Synthetic models for non-heme carboxylate-bridged diiron metalloproteins: strategies and tactics. Chem. Rev. 2004, 104, 987-1012.

(10) Friedle, S.; Reisner, E.; Lippard, S. J. Current challenges of modeling diiron enzyme active sites for dioxygen activation by biomimetic synthetic complexes. Chem. Soc. Rev. 2010, 39, 27682779.

(11) (a) Chan, S. I.; Lu, Y.-J.; Nagababu, P.; Maji, S.; Hung, M.-C.; Lee, M. M.; Hsu, I.-J.; Minh, P. D.; Lai, J. C.-H.; Ng, K. Y.; Ramalingam, S.; Yu, S. S.-F.; Chan, M. K. Efficient oxidation of methane to methanol by dioxygen mediated by tricopper clusters. Angew. Chem., Int. Ed. 2013, 52, 3731-3735. (b) Nagababu, P.; Yu, S.
S. F.; Maji, S.; Ramu, R.; Chan, S. I. Developing an efficient catalyst for controlled oxidation of small alkanes under ambient conditions. Catal. Sci. Technol. 2014, 4, 930-935. (c) Liu, C. C.; Mou, C. Y.; Yu, S. S. F.; Chan, S. I. Heterogeneous formulation of the tricopper complex for efficient catalytic conversion of methane into methanol at ambient temperature and pressure. Energy Environ. Sci. 2016, 9, 1361-1374. (d) Smeets, P. J.; Hadt, R. G.; Woertink, J. S.; Vanelderen, P.; Schoonheydt, R. A.; Sels, B. F.; Solomon, E. I. Oxygen Precursor to the Reactive Intermediate in Methanol Synthesis by Cu-ZSM-5. J. Am. Chem. Soc. 2010, 132, 14736-14738. (e) Woertink, J. S.; Smeets, P. J.; Groothaert, M. H.; Vance, M. A.; Sels, B. F.; Schoonheydt, R. A.; Solomon, E. I. A $\left[\mathrm{Cu}_{2} \mathrm{O}\right]^{2+}$ core in $\mathrm{Cu}-$ ZSM-5, the active site in the oxidation of methane to methanol. Proc. Natl. Acad. Sci. U. S. A. 2009, 106, 18908-18913. (f) Grundner, S.; Markovits, M. A. C.; Li, G.; Tromp, M.; Pidko, E. A.; Hensen, E. J. M.; Jentys, A.; Sanchez-Sanchez, M.; Lercher, J. A. Single-site trinuclear copper oxygen clusters in mordenite for selective conversion of methane to methanol. Nat. Commun. 2015, 6, 7546.

(12) (a) Sorokin, A. B.; Kudrik, E. V.; Bouchu, D. Bio-inspired oxidation of methane in water catalyzed by N-bridged diiron phthalocyanine complex. Chem. Commun. 2008, 2562-2564. (b) İşci, Ü.; Faponle, A. S.; Afanasiev, P.; Albrieux, F.; Briois, V.; Ahsen, V.; Dumoulin, F.; Sorokin, A. B.; de Visser, S. P. Site-selective formation of an iron(IV)-oxo species at the more electron-rich iron atom of heteroleptic $\mu$-nitrido diiron phthalocyanines. Chem. Sci. 2015, 6, 5063-5075. (c) Quesne, M. G.; Senthilnathan, D.; Singh, D.; Kumar, D.; Maldivi, P.; Sorokin, A. B.; de Visser, S. P. Origin of the enchanced reactivity of $\mu$-nitrido-bridged diiron(IV)-oxo porphyrinoid complexes over cytochrome P450 Compound I. ACS Catal. 2016, 6, 2230-2243. (d) Afanasiev, P.; Sorokin, A. B. $\mu$-Nitrido diiron macrocyclic platform: particular structure for particular catalysis. Acc. Chem. Res. 2016, 49, 583-593.

(13) Kudrik, E. V.; Afanasiev, P.; Alvarez, L. X.; Blondin, G.; Dubourdeaux, P.; Clémancey, M.; Latour, J.-M.; Bouchu, D.; Albrieux, F.; Nefedov, S. E.; Sorokin, A. B. An N-bridged high-valent diiron-oxo species on a porphyrin platform that can oxidize methane. Nat. Chem. 2012, 4, 1024-1029.

(14) Dinh, K. T.; Sullivan, M. M.; Serna, P.; Meyer, R. J.; Dincă, M.; Román-Leshkov, Y. Viewpoint on the partial oxidation of methane to methanol using $\mathrm{Cu}-$ and $\mathrm{Fe}$-exchanged zeolites. ACS Catal. 2018, 8, $8306-8313$.

(15) (a) Das, S.; Incarvito, C. D.; Crabtree, R. H.; Brudvig, G. W. Molecular recognition in the selective oxygenation of saturated $\mathrm{C}-\mathrm{H}$ bonds by a dimanganese catalyst. Science 2006, 312, 1941-1943. (b) Olivo, G.; Farinelli, G.; Barbieri, A.; Lanzalunga, O.; Di Stefano, S.; Costas, M. Supramolecular recognition allows remote, siteselective C-H oxidation of methylenic sites in linear Amines. Angew. Chem., Int. Ed. 2017, 56, 16347-16351.

(16) Belvedere, S.; Breslow, R. Regioselective Oxidation of Steroids by a Manganese Porphyrin Carrying Metal Coordinating Groups. Bioorg. Chem. 2001, 29, 321-331.

(17) Breslow, R.; Huang, Y.; Zhang, X.; Yang, J. An artificial cytochrome $\mathrm{P} 450$ that hydroxylates unactivated carbons with regioand stereoselectivity and useful catalytic turnovers. Proc. Natl. Acad. Sci. U. S. A. 1997, 94, 11156-11158.

(18) Vidal, D.; Olivo, G.; Costas, M. Controlling Selectivity in Aliphatic C-H Oxidation through Supramolecular Recognition. Chem. - Eur. J. 2018, 24, 5042-5054.

(19) Perraud, O.; Sorokin, A. B.; Dutasta, J.-P.; Martinez, A. Oxidation of cycloalkanes by $\mathrm{H}_{2} \mathrm{O}_{2}$ using a copper-hemicryptophane complex as a catalyst. Chem. Commun. 2013, 49, 1288-1290.

(20) Zhang, D.; Jamieson, K.; Guy, L.; Gao, G.; Dutasta, J. P.; Martinez, A. Tailored oxido-vanadium(V) cage complexes for selective sulfoxidation in confined spaces. Chem. Sci. 2017, 8, 789794.

(21) (a) Kaphan, D. M.; Levin, M. D.; Bergman, R. G.; Raymond, K. N.; Toste, F. D. A supramolecular microenvironment strategy for transition metal catalysis. Science 2015, 350, 1235-1238. (b) Shenoy, S. R.; Pinacho Crisóstomo, F. R.; Iwasawa, T.; Rebek, J., Jr. 
Organocatalysis In a Synthetic Receptor with an Inwardly Directed Carboxylic Acid. J. Am. Chem. Soc. 2008, 130, 5658-5659. (c) GarcíaSimón, C.; Gramage-Doria, R.; Raoufmoghaddam, S.; Parella, T.; Costas, M.; Ribas, X.; Reek, J. N. H. Enantioselective Hydroformylation by a Rh-Catalyst Entrapped in a Supramolecular Metallocage. J. Am. Chem. Soc. 2015, 137, 2680-2687.

(22) Zhang, D.; Dutasta, J. P.; Dufaud, V.; Guy, L.; Martinez, A. Sulfoxidation inside a $\mathrm{C}_{3}$-vanadium $(\mathrm{V})$ bowl-shaped catalyst. ACS Catal. 2017, 7, 7340-7345.

(23) Zhang, D.; Bousquet, B.; Mulatier, J. C.; Pitrat, D.; Jean, M.; Vanthuyne, N.; Guy, L.; Dutasta, J. P.; Martinez, A. Synthesis, Resolution, and Absolute Configuration of Chiral Tris(2pyridylmethyl)amine-Based Hemicryptophane Molecular Cages. J. Org. Chem. 2017, 82, 6082-6088.

(24) (a) Łabanowska, M.; Bidzinska, E.; Para, A.; Kurdziel, M. EPR investigation of $\mathrm{Cu}(\mathrm{II})$-complexes with nitrogen derivatives of dialdehyde starch. Carbohydr. Polym. 2012, 87, 2605-2613. (b) Sasmal, A.; Garribba, E.; Rizzoli, C.; Mitra, S. Reversible Switching of Electronic Ground State in a Pentacoordinated $\mathrm{Cu}$ (II) 1D Cationic Polymer and Structural Diversity. Inorg. Chem. 2014, 53, 6665-6674. (c) Hall, N.; Orio, M.; Gennari, M.; Wills, C.; Molton, F.; Philouze, C.; Jameson, G. B.; Halcrow, M. A.; Blackman, A. G.; Duboc, C. Multifrequency cw-EPR and DFT Studies of an Apparent Compressed Octahedral $\mathrm{Cu}$ (II) Complex. Inorg. Chem. 2016, 55, 1497-1504.

(25) Diebold, A.; Hagen, K. S. Iron(II) Polyamine Chemistry: Variation of Spin State and Coordination Number in Solid State and Solution with Iron(II) Tris(2-pyridylmethyl)amine Complexes. Inorg. Chem. 1998, 37, 215-223.

(26) Garel, L.; Dutasta, J. P.; Collet, A. Complexation of Methane and Chlorofluorocarbons by Cryptophane-A in Organic Solution. Angew. Chem., Int. Ed. Engl. 1993, 32, 1169-1171.

(27) Zhiquan, L.; Xie, H.; Border, S. E.; Gallucci, J.; Pavlović, R. Z.; Badjić, J. D. A stimuli-responsive molecular capsule with switchable dynamics, chirality, and encapsulation characteristics. J. Am. Chem. Soc. 2018, 140, 11091-11100.

(28) This solvent $\left(108 \AA^{3}\right)$ is much larger than $\mathrm{CH}_{4}\left(33 \AA^{3}\right)$, weakening the competitive interaction between the solvent and the cavity of Hm-TPA.

(29) Control experiments were performed in the absence of $\mathrm{CH}_{4}$, which produced a small quantity of oxidized products due to degradation of the organic ligand. Tables $1-3$ give the corrected values of TON in oxidized products due to methane oxidation, i.e., after subtraction of the amounts of products obtained during the control experiments (without $\mathrm{CH}_{4}$ ). We could not detect $\mathrm{CO}_{2}$ by our analytical tools, although the formation of small amounts of $\mathrm{CO}_{2}$ cannot be excluded.

(30) Keown, W.; Gary, J. B.; Stack, T. D. P. High-valent copper in biomimetic and biological oxidations. JBIC, J. Biol. Inorg. Chem. 2017, 22, 289-305.

(31) Garcia-Bosch, I.; Siegler, M. A. Copper-Catalyzed Oxidation of Alkanes with $\mathrm{H}_{2} \mathrm{O}_{2}$ under a Fenton-like Regime. Angew. Chem., Int. Ed. 2016, 55, 12873-12876.

(32) (a) Lim, M. H.; Rohde, J. U.; Stubna, A.; Bukowski, M. R.; Costas, M.; Ho, R. Y. N.; Münck, E.; Nam, W.; Que, L., Jr. An Fe ${ }^{\mathrm{IV}}=$ O complex of a tetradentate tripodal nonheme ligand. Proc. Natl. Acad. Sci. U. S. A. 2003, 100, 3665-3670. (b) Oloo, W. N.; Banerjee, R.; Lipscomb, J. D.; Que, L., Jr. Equilibrating (L)Fe $\mathrm{Fe}^{\mathrm{III}}-\mathrm{OOAc}$ and (L) $\mathrm{Fe}^{\mathrm{V}}(\mathrm{O})$ Species in Hydrocarbon Oxidations by Bio-Inspired Nonheme Iron Catalysts Using $\mathrm{H}_{2} \mathrm{O}_{2}$ and AcOH. J. Am. Chem. Soc. 2017, 139, 17313-17326. (c) Serrano-Plana, J.; Acuna-Parés, F.; Dantignana, V.; Oloo, W. N.; Castillo, E.; Draksharapu, A.; Whiteoak, C. J.; Martin-Diaconescu, V.; Basallote, M. G.; Luis, J. M.; Que, L., Jr.; Costas, M.; Company, A. Acid Triggered O-O Bond Heterolysis of a Nonheme $\mathrm{Fe}^{\mathrm{III}}(\mathrm{OOH})$ Species for the Stereospecific Hydroxylation of Strong C-H Bonds. Chem. - Eur. J. 2018, 24, 5331-5340.

(33) Shul'pin, G. B.; Nizova, G. V.; Kozlov, Y. N.; Gonzalez Cuervo, L.; Süss-Fink, G. Hydrogen Peroxide Oxygenation of Alkanes
Including Methane and Ethane Catalyzed by Iron Complexes in Acetonitrile. Adv. Synth. Catal. 2004, 346, 317-332. 